\title{
Nutritional Compositions of Baccaurea sapida and Eleaocarpus sikkimnesis of Sikkim Himalaya
}

\author{
Yamuna Pandey ${ }^{*}$, S. Upadhyay ${ }^{1}$, S.S. Bhatt ${ }^{2}$, L. Sharma ${ }^{1}$, \\ S. Manivannan ${ }^{1}$ and C. Chanbisana ${ }^{3}$
}

${ }^{1}$ Department of Horticulture, Sikkim University, India

${ }^{2}$ College of Agriculture, Dev Bhoomi Institute of Technology, India

${ }^{3}$ College of Horticulture (Thenzawl) CAU, India

*Corresponding author

\begin{abstract}
A B S T R A C T
Keywords

Baccaurea sapida,

Eleaocarpus

sikkimnesis,

Nutrient content

Article Info

Accepted:

17 January 2018

Available Online:

10 February 2018

Sikkim Himalaya has huge diversity of wild edible fruits which has immense nutritional values. Keeping the view of vital nutritional potential of wild fruits, present study had conducted at laboratory of Department of Horticulture, Sikkim University to assess the nutrient content like crude protein, crude fat, crude fibre, carbohydrate, energy value, ash, moisture and dry matter and some mineral elements like $\mathrm{Ca}, \mathrm{K}, \mathrm{Mg}, \mathrm{Na}, \mathrm{Mo}, \mathrm{Cu}, \mathrm{Fe}$ and Zn of two under utilized fruit crops viz. Baccaurea sapida and Eleaocarpus sikkimnesis from Sikkim Himalayas. The present study revealed that the fruit of Eleaocarpus sikkimnesis contains highest calorific value that is $389.56 \pm 3.29 \mathrm{kcal} / \mathrm{kg}$ as compared to Baccaurea sapida $(377.44 \pm 3.26 \mathrm{kcal} / \mathrm{g})$. Crude protein $(6.93 \pm 0.03)$ and available carbohydrate $(88.17 \pm 0.80)$ per cent was also noted highest in Eleaocarpus sikkimnesis.

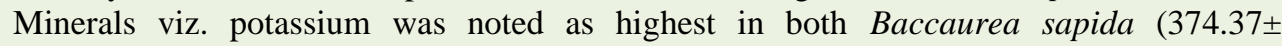
$9.68 \mu \mathrm{g} / \mathrm{L})$ and Eleaocarpus sikkimnesis $(223.59 \pm 6.21 \mu \mathrm{g} / \mathrm{L})$. Other elements like $\mathrm{Na}, \mathrm{Cu}$, $\mathrm{Mg}, \mathrm{Ca}, \mathrm{Fe}$, and $\mathrm{Mn}$ were noted significantly in a range of 7.99 to $37.29 \mu \mathrm{g} / \mathrm{L}$ in Baccaurea sapida which was highest than that of Eleaocarpus sikkimnesis.
\end{abstract}

\section{Introduction}

Sikkim, a North-Eastern State of India is one of the few places on earth with such a unique biodiversity comprising different agroclimatic zones with a wide range of plant species having medicinal and nutritional properties. Due to high forest coverage the state wild edible plants are being highly consumed in the daily diet of the local people and they directly rely on wild plant species and their genetic resources for food and medicine. Fruit species, particularly those currently identified as 'underutilized', can contribute significantly to improve human health and nutrition, livelihoods, household food security and ecological sustainability which constitute an essential component in the diet of many ethnic population. The diversity of underutilized or wild edible lesser known plants species is very high (>250 species) in the Sikkim Himalaya. The 
majority of these species are considered as poor man's food (Sharma et al., 2016). Underutilized fruits are vital source of an adequate diet and they serve as food supplements, appetizer and sometimes the nutritional values of underutilized fruits are found higher than several known cultivated food yielding species as reported by Orech et al., (2007), but very few nutritional studies have emphasized over the significant benefits of such fruit species. Keeping the above points in mind, the nutritional constituents of two under utilized fruits of Sikkim Himalayas like Baccaurea sapida and Elaeocarpus sikkimensis were studied and discussed in the current proposed research paper.

Baccaurea sapida (Phyllanthaceae)is native to the Southeast Asian region and found growing wild as well as under cultivation in Nepal, India, Myanmar, South China, IndoChina, Thailand, the Andaman Islands, and Peninsular Malaysia. It is an underutilized fruit species locally known as Kusum. The different species of Baccaurea is found in Sikkim, Darjeeling, Arunachal Pradesh, Assam, Meghalaya, Tripura, Mizoram and Manipur. It is a semi deciduous tree small to medium in size, approximately $8-10 \mathrm{~m}$ in height. Generally ripe fruits are edible and the colour of the fruit is yellowish to pinkish pulpy aril uses as table fruit. Fruits are glabrous of size 25 to $30 \mathrm{~mm}$ in diameter. The fruits ripened during June - July which sold in the local market at Rs. 40/kg. The fruit is used to cure the skin diseases.

Eleaocarpus sikkimensis (Elaeocarpaceae)It is woody evergreen large tree that grows up to $40 \mathrm{~m}$ high. Leaves are clustered spirally arranged near the end of the branches. Fruit is ellipsoidal from broad base, greenish in colour. The stone fruits have one to five chambers. Ripe fruits are available during November- December. Edible fruits are used to make pickles and chutneys. Different species of Elaeocarpus are very important in the field of medical science due to the presence of their phytochemicals with their high medicinal values. Mainly these chemicals are alkaloids, flavonoids, tannins, glycosides, and ellagic acid derivatives (Dadhich et al., 2013).

\section{Materials and Methods}

The present investigation entitled "Nutritional composition of Baccaurea sapida and Eleaocarpus sikkimnesis fruits of Sikkim Himalayas." was carried out at Laboratory of Department of Horticulture, Sikkim University during the year 2014-2017. Experiment was conducted on two underutilized fruits grown naturally at forest vegetation of Sikkim Himalayas were directly collected from the forest area of different region of Sikkim. Nutritional component viz. crude protein, crude fat, crude fibre, available carbohydrate, energy value, ash, moisture and dry matter content and some vital elements were estimated using standard method of chemical analysis which is mentioned below:

\section{Moisture and dry matter content}

Moisture and Dry matter content were determined by following the method given by A.O.A.C, 1990. Weighed sample $(5.0 \mathrm{~g})$ of each fresh fruit was taken in a sterilize weighed petri dish and kept in the hot air oven at $105^{\circ} \mathrm{C}$ for 12 hours and petri dish were then allowed to cool and weighed.

The loss in weight represents the moisture content of the sample whereas, the dry matter content of the sample represents the amount of material left after the complete removal of moisture from the sample. The per cent moisture and dry matter content from the fruit sample were calculated by using the following formula: - 
(Weight of fresh sample - Weight of dry sample) Moisture content $(\%)=$

Weight of fresh sample

(Weight of petri dish + Weight of dried sample)Weight of dish

Dry matter $(\%)=$

Weight of sample before drying

\section{Ash content}

Ash content was determined by following the method of A.O.A.C., 1990. For this crucible were kept in a muffle furnace at $600^{\circ} \mathrm{C}$ for $1 \mathrm{~h}$. Then they were transferred from furnace and cooled to room temperature and weighed $\left(\mathrm{W}_{1}\right)$ as quickly as possible to prevent moisture absorption. $2 \mathrm{~g}$ dried fruit sample was taken in crucible and placed in a muffle furnace at $600^{\circ} \mathrm{C}$ for $6 \mathrm{~h}$. Then crucible was transferred to cool at room temperature and weighed $\left(\mathrm{W}_{2}\right)$, Then the percentage of ash was calculated by using the following formula:-

$$
\operatorname{Ash}(\%)=\frac{\mathrm{W}_{2}-\mathrm{W}_{1}(\text { weight of ash) }}{\text { Weight of sample }}
$$

\section{Crude fibre}

Crude fibre was analyzed using fibre estimation system, model no Fibra plus-FES 04 AS DLS, PELICAN. $2 \mathrm{~g}$ of moisture and fat free sample were taken in the crucibles then it was loaded in the instrument. $150 \mathrm{ml}$ of $1.25 \%$ of $\mathrm{H}_{2} \mathrm{SO}_{4}$ was added from the top and boiled at $500^{\circ} \mathrm{C}$ for 30 minutes. Once the boiling was completed the reagents was drained out with the help of fibra flow then $150 \mathrm{ml}$ of $1.25 \% \mathrm{NaOH}$ was added from the top and heat the sample at $400^{\circ} \mathrm{C}$ for 45 minutes which led to digestion of sample. After completion of digestion reagents was drained out and residue was dried in hot air oven at $90-100^{\circ} \mathrm{C}$ and cooled and weighed the dried residue (W1) then the residue was kept in pre-weighed porcelain crucible and put in the muffle furnace for ashes at $600{ }^{\circ} \mathrm{C}$ in 3 hours then it was cooled and weighed $\left(\mathrm{W}_{2}\right)$. Crude fibre content was expressed as percentage loss in weight on ignition (A.O.A.C., 1990) and calculated using following formula:

$$
\text { Crude Fibre }(\%)=\frac{\mathrm{W}_{1}-\mathrm{W}_{2}}{\text { Weight of sample }}
$$

\section{Crude fat}

Crude fat content was determined by soxhlet principle with slight modification (A.O.A.C, 1990) The fat from the oven dried fruit sample was extracted in essential oil extractor (model no. Socsplus-SCS 06 DLS, PELICAN) using petroleum ether as solvent then ether is evaporated and determined the weight of the fat recovered using following formula:

$$
\text { Crude Fat }(\%)=\frac{\mathrm{W}_{2}-\mathrm{W}_{1}}{\text { Weight of sample }}
$$

\section{Crude protein}

The crude protein was estimated by Lowry's method (Lowry et al., 1951) by using UV/VIS Spectrophotometer, Perkin Elmer, Lambda 35 UV/VIS spectrometer.

\section{Available carbohydrate}

The percentage of available carbohydrate was calculated by: 100- (Percentage of ash+ Percentage of fat + Percentage of fibre + Percentage of protein) (A.O.A.C., 1990).

\section{Energy value/nutritive value}

The energy value in kilocalorie per gram (Kcal/g) was determined by multiplying the percentage of crude proteins, crude fat and carbohydrate by the recommended factor 4,9 and 4 , respectively and then taken the sum of 
values. The value was then converted to kilojoules by multiplying with 4.2 (A.O.A.C., 1990)

Energy value $(\mathrm{Kcal} / \mathrm{g})=(\mathrm{CP} \times 4)+(\mathrm{CF} \times 9)+$ (Carb. x 4)

\section{Minerals}

ICP-MS (Inductively Coupled Plasma Mass Spectrophotometry) Perkin Elmer Nex ION $300 \mathrm{X}$ was used for estimation of some mineral elements. Digested samples were analyzed for the ionic constitution using multi elements standards for detecting the elements such as $\mathrm{Ca}$, $\mathrm{Fe}, \mathrm{Mg}, \mathrm{Mn}, \mathrm{Mo}, \mathrm{Na}, \mathrm{Zn}$. The micro wave digestion system (Anton par microwave 3000) was used for sample digestion as $0.5 \mathrm{gm}$ sample were along $9 \mathrm{ml}$ of $69 \%$ nitric acid and $2 \mathrm{ml} \mathrm{HCl}$ were added into the digestion tube and run the instrument for 40 minutes. The digested samples were then transferred into $50 \mathrm{ml}$ volumetric flask when the temperature of the sample was reduced and distilled water was added for making the volume of $50 \mathrm{ml}$. The liquid sample was transferred into narrow mouth bottle until the minerals were determined in ICP-MS. The values of the elements were expressed as $\mu \mathrm{g} / \mathrm{L}$.

\section{Statistical analysis}

All the assays were carried out in triplicate and values were obtained by calculating the average of three experiments using Microsoft excel programmed (Microsoft excel-10) and data are presented as Mean \pm standard deviation.

\section{Results and Discussion}

\section{Moisture and dry matter content}

The moisture content is one of the important factors amongst the physical properties of edible fruits that may vary due to changing its value in nutritional composition. In the present study moisture content was found to be higher in the fruit of Baccaurea sapida i.e. $81.17 \pm 0.65$ $\%$ then Eleaocarpus sikkimenss $(68.67 \pm 0.40)$. our finding regarding moisture content in the fruit of Baccauresapida is similar to the finding of (Mann et al., 2016)(81.65 \%). Dry matter content was observed as $31.33 \pm 0.40 \%$ in Eleaocarpus sikkimenss and $81.17 \pm 0.65 \%$ in Baccaurea sapida.

\section{Fiber and ash content}

Fibre rich diets are essential for effective removal of waste and percentage of ash represents the mineral content that is present in the fruits. It was noted that $3.59 \pm 0.72 \%$ of ash and $3.60 \pm 0.03 \%$ of Fiber content was estimated from the fruit of Baccaurea sapida whereas, $1.88 \pm 0.78 \%$ and $2.0 \pm 0.05 \%$ of ash and fiber, respectively were obtained from the fruit of Eleaocarpus sikkimnesis. Mann et al (2016)also reported the dietary fibre of pulp of Baccaurea sapida as $3.6 \mathrm{~g} / 100 \mathrm{~g}$ and the ash content of pulp and peel of Baccaurea sapida reported to be $5.42 \mathrm{~g} / 100 \mathrm{~g}$ and $5.31 \mathrm{~g} / 100 \mathrm{~g}$, respectively. There is not much research evidence found for Eleaocarpus sikkimnesis.

\section{Crude fat and crude protein}

Crude fat content was noted as $1.24 \pm 0.09 \%$ in Baccaurea sapida and $1.02 \pm 0.03 \%$ in Eleaocarpus sikkimnesis and crude protein content in Baccaurea sapida and Eleaocarpus sikkimnesiswas found to be $5.43 \pm 0.87 \%$ and $6.93 \pm 0.03 \%$, respectively. Bhutia (2013)also reported $6.5 \%$ protein and $0.3 \%$ fat in the fruit of Eleaocarpus sikkimensis which was similar to our recent finding. Seal et al (2014) reported $6.94 \%$ crude protein in the fruits of Baccaurea sapida which is slightly higher than our finding.

\section{Available carbohydrate and Energy value}

Available carbohydrate content was found to be highest as $88.17 \pm 0.80 \%$ in the fruit of Eleaocarpus sikkimensis whereas, the fruit of Baccaurea sapida contains $86.14 \pm 1.49 \%$. As far as Energy value/ nutritive value is concerned it was observed highest in Eleaocarpus sikkimensis than Baccaurea sapida i.e. $389.56 \pm 3.29 \mathrm{Kcal} / \mathrm{g}$ and $377.44 \pm 3.26 \mathrm{Kcal} / \mathrm{g}$, 
respectively. Ibrahim et al (2013) reported 74.14 per cent of carbohydrate content in the freeze-dried fruits of Baccaurea angulate. The fruits having good composition of carbohydrates are very nutritious for health products and responsible for their high calorific value (Ozcan, et al., 2007). The nutritional composition like moisture and dry matter content, Ash, fibre, fat, protein, carbohydrate and energy value table 1 .

Table.1 Nutritional composition of Baccaurea sapida and Eleaocarpus sikkimnesis

\begin{tabular}{|c|l|l|l|}
\hline Sl. No. & Nutritional Parameters (\%) & Baccaurea sapida & Eleaocarpus sikkimnesis \\
\hline 1. & Moisture content & $81.17 \pm 0.65$ & $68.67 \pm 0.40$ \\
\hline 2. & Dry Matter content & $18.83 \pm 0.65$ & $31.33 \pm 0.40$ \\
\hline 3. & Ash content & $3.59 \pm 0.72$ & $1.88 \pm 0.78$ \\
\hline 4. & Fibre & $3.60 \pm 0.03$ & $2.0 \pm 0.05$ \\
\hline 5. & Crude Fat & $1.24 \pm 0.09$ & $1.02 \pm 0.03$ \\
\hline 6. & Crude Protein & $5.43 \pm 0.87$ & $6.93 \pm 0.03$ \\
\hline 7. & Available Carbohydrate & $86.14 \pm 1.49$ & $88.17 \pm 0.80$ \\
\hline 8. & Energy value (Kcal/g) & $377.44 \pm 3.26$ & $389.56 \pm 3.29$ \\
\hline
\end{tabular}

Table.2 Minerals content of Baccaurea sapidaandEleaocarpus sikkimnesis( $\mu \mathrm{g} / \mathrm{L})$

\begin{tabular}{|c|l|l|l|}
\hline Sl. No. & Minerals content $(\boldsymbol{\mu g} / \mathbf{L})$ & Baccaurea sapida & Eleaocarpus sikkimnesis \\
\hline 1. & Calcium & $23.77 \pm 2.0$ & $2.89 \pm 0.32$ \\
\hline 2. & Magnesium & $21.67 \pm 1.2$ & $21.67 \pm 1.4$ \\
\hline 3. & Potassium & $375.37 \pm 9.68$ & $223.59 \pm 6.21$ \\
\hline 4. & Molybdenum & $1.03 \pm 0.12$ & $1.99 \pm 0.9$ \\
\hline 5. & Sodium & $7.99 \pm 1.8$ & $8.09 \pm 1.6$ \\
\hline 6. & Zinc & $0.97 \pm 0.18$ & $0.33 \pm 0.8$ \\
\hline 7. & Iron & $29.55 \pm 2.6$ & $24.29 \pm 2.3$ \\
\hline 8. & Copper & $14.33 \pm 1.2$ & $4.27 \pm 0.96$ \\
\hline 9. & Manganese & $37.29 \pm 3.8$ & $11.46 \pm 1.1$ \\
\hline
\end{tabular}

\section{Minerals}

Among all the essential elements, potassium content was found to be highest as the value of $375.37 \pm 9.68 \mu \mathrm{g} / \mathrm{L}$ and $223.59 \pm 6.21 \mu \mathrm{g} / \mathrm{L}$ in the fruit of Baccaurea sapida and Eleaocarpus sikkimnesis, respectively. Manganese was noted highest in Baccaurea sapida $(37.29 \pm 3.8 \mu \mathrm{g} / \mathrm{L})$ and lowest in Eleaocarpus sikkimnesis (11.46 \pm $1.1 \mu \mathrm{g} / \mathrm{L})$. Significant amount of iron was also noted in a range of $29.55 \pm 2.6 \mu \mathrm{g} / \mathrm{L}$ to $24.29 \pm$ $2.3 \mu \mathrm{g} / \mathrm{L}$ in the fruit of Baccaurea sapida and Eleaocarpus sikkimnesis, respectively. Calcium content was found as $23.77 \pm 2.0 \mu \mathrm{g} / \mathrm{L}$ which is highest in the fruit of Baccaurea sapida whereas, the fruit of Eleaocarpus sikkimnesis contains only $2.89 \pm 0.32 \mu \mathrm{g} / \mathrm{L}$. Elements like magnesium, copper, sodium and zinc were observed in a range of $21.67 \pm 1.2 \mu \mathrm{g} / \mathrm{L}, 14.33$ $\pm 1.2 \mu \mathrm{g} / \mathrm{L}, 7.99 \pm 1.8 \mu \mathrm{g} / \mathrm{Land} 0.97 \pm 0.18 \mu \mathrm{g} / \mathrm{L}$ respectively, in the fruit of Baccaurea sapidaand range of $21.67 \pm 1.4 \mu \mathrm{g} / \mathrm{L}, 4.27 \pm$ $0.96 \mu \mathrm{g} / \mathrm{L}, 8.09 \pm 1.6 \mu \mathrm{g} / \mathrm{L}$ and $0.33 \pm 0.8 \mu \mathrm{g} / \mathrm{L}$ respectively, in Eleaocarpus sikkimnesis. Rai et al., (2005) reported the appreciable amount of mineral concentration from the wild edible fruits of Sikkim which was similar to our findings. The data related to minerals are presented in the table 2 . 


\section{Acknowledgement}

Author of this paper is highly grateful to honorable Vice Chancellor Prof. T. B. Subba and Dean, School of life science Prof. J. P Tamang, Sikkim University for their constant support, encouragement and providing facilities for research work. I am also thankful to all the advisory committee of my Ph.D. for their immense support.

\section{References}

A.O.A.C. 1990. Official Methods of Analysis. $15^{\text {th }}$ Edn., Association of Official Methods of

Analytical Chemists, Washington, DC., Arlington, Virginia, USA., ISBN: 0935584-42-0.

Bhutia, K. D. 2013. Studies on the physicochemical characteristics and utilization aspects of some indigenous minor fruits of Sikkim. Ph. D thesis, Department of Pomology and Post Harvest Technology, Uttar Banga Krishi Vishwavidyalaya.

Dadhich, A., Rishi, A., Sharma, G. and Chandra, S. 2013.Phytochemicals of Elaeocarpus with their Therapeutic value: a review. International Journal of Pharma and Bio Sciences. 4(3): 591 - 598.

Ibrahim, D., Hazali, N., Jauhari, N., Omar, M.N., Yahya, MNA., Ahmed, I. A., Mikail, M. A., and

Ibrahim, M. 2013.Physicochemical and antioxidant characteristics of Baccaurea angulate fruit juice extract. African Journal of Biotechnology.12(34): 5333-
5338.

Lowry, O.H., Rosebrough, N.J., Farr, A.L., and Randall, R..J. 1951. Protein measurement with the Folin Phenol Reagent. Journal of Biological Chemistry. 193: 265 -275.

Mann, S., Satpathy, G. and Gupta, R. K. 2016. Evaluation of nutritional and phytochemical profiling of Baccaurea ramiflora Lour. Syn. Baccaurea sapida (Roxb.) Mull. Arg. Fruits. Indian Journal of Traditional Knowledge. 15(1): 135142.

Orech, F.O., Hansen, J.A., and Friis, H. 2007. Ethnoecology of traditional leafy vegetables of the

Luo people of Bondo district, western Kenya. International Journal of Food Science and Nutrition. 58(7): 522-530.

Ozcan, M. M., Haciseferogullari, H. 2007. The strawberry (Abutus unedo L.) fruits: Chemical composition, physicalproperties and mineral contents. Journal of Food Engineering. 78: 1022-8

Rai, A.K., Sharma, R.M. and Tamang J.P. 2005. Food value of common wild plants of Sikkim. Journal of Hill research. 18(2): 99-103.

Seal, T., Pillai, B. and Chaudhuri, K. 2014. Nutritional Potential of wild edible fruits, traditionally used by the local people of Meghalaya state in India. Indian Journal of Natural Product and Resources. 5(4): 359-364.

Sharma, G., Pratap, U., Sharma, E., Rasul, G. and Avasthe, R. K. 2016. Agro Biodiversity in

Sikkim Himalaya, ICIMOD working paper $2016 / 5$.

\section{How to cite this article:}

Yamuna Pandey, S. Upadhyay, S.S. Bhatt, L. Sharma, S. Manivannan and Chanbisana, C. 2018. Nutritional Compositions of Baccaurea sapida and Eleaocarpus sikkimnesis of Sikkim Himalaya. Int.J.Curr.Microbiol.App.Sci. 7(02): 2101-2106. https://doi.org/10.20546/ijcmas.2018.702.250 